\title{
Regioselectively Modified Stereoregular Polysaccharides XIII. Polymerization of 3-Deoxygenated 1,6- Anhydroglucopyranose Derivative
}

\author{
Kazukiyo Kobayashi, Hiroshi Sumitomo, and Hiroshi Shiozawa \\ Faculty of Agriculture, Nagoya University, Chikusa, Nagoya 464, Japan
}

(Received July 13, 1988)

\begin{abstract}
Ring-opening homo- and copolymerization of a 3-deoxygenated anhydro sugar derivative (1,6-anhydro-2,4-di- $O$-benzyl-3-deoxy- $\beta$-D-ribo-hexopyranose, 1) was carried out using phosphorus pentafluoride as the initiator in dichloromethane. Homopolymerization of 1 at $-60^{\circ} \mathrm{C}$ gave highly stereoregular polymers with $\alpha$-configuration and with number average molecular weight of $12.8 \times 10^{4}-2.9 \times 10^{4}$. The highest yield was $95.6 \%$. The monomer reactivity ratios in copolymerization of 1 with 1,6-anhydro-2,3,4-tri- $O$-benzyl- $\beta$-D-glucopyranose (2) at $-60^{\circ} \mathrm{C}$ were $r_{1}=1.60$ and $r_{2}=0.73$. The equilibrium monomer concentrations $\left([\mathrm{M}]_{\mathrm{e}}\right)$ of 1 and 2 were $0.029-0.042 \mathrm{moll}^{-1}$ and $0.0064 \mathrm{moll}^{-1}$, respectively $\left(-60^{\circ} \mathrm{C}\right)$. Hydrolysis of $\mathbf{1}$ and $\mathbf{2}$ in a solution of trifluoroacetic acid and deuterium oxide (volume ratio of $6: 4$ ) proceeded at a respective rate of $2.4 \times 10^{-5} \mathrm{~s}^{-1}$ and $7.3 \times 10^{-6} \mathrm{~s}^{-1}\left(60^{\circ} \mathrm{C}\right)$. Debenzylation of the homo- and copolymers using sodium in liquid ammonia yielded linear $(1 \rightarrow 6)-\alpha$-D-glucopyranans with different degree of 3-deoxygenation.

KEY WORDS Anhydro Sugar/Ring-Opening Polymerization/Synthetic Polysaccharide / Deoxygenated Polysaccharide /
\end{abstract}

Biologically important deoxysugars occur widely in nature as components of cardiac glycosides, antibiotics and antigenic determinants. ${ }^{1}$ Recent attention has been given to synthetic deoxy oligosaccharides which serve as receptor analogues for investigating molecular recognition of enzymes, lectins, and monoclonal antibodies. ${ }^{2.3}$ In this respect, welldefined deoxygenated polysaccharides whose structures are slightly different from naturally occuring ones are an important model system to understand the principles of the specificity of structure-function relationship. Synthesis of polysaccharides having well-defined structures have been attempted via ring-opening polymerization $^{4,5}$ and polycondensation. ${ }^{6}$

In this study, regiospecifically deoxygenated $(1 \rightarrow 6)-\alpha$-D-glucopyranans were prepared according to Scheme I: homopolymerization of 1,6-anhydro-2,4-di- $O$-benzyl-3-deoxy- $\beta$-Dribo-hexopyranose $(\mathbf{1})^{7}$ and its copolymeri- zation with 1,6-anhydro-2,3,4-tri- $O$-benzyl- $\beta$ D-glucopyranose (2), followed by debenzylation of the resulting homo- and copolymers. The polysaccharide obtained differed from linear dextran in replacing its equatorial hydroxyl groups on C-3 carbons by hydrogen atoms. ${ }^{8}$ The polymerization reactivity of 1 was examined for comparison with those of some related compounds. ${ }^{9-15}$

\section{EXPERIMENTAL}

Scheme II shows the synthetic method of 1,6-anhydro-2,4-di- $O$-benzyl-3-deoxy- $\beta$-Dribo-hexopyranose (1) via four step reactions starting from microcrystalline cellulose. 1,6Anhydro-2,4-di- $O$-benzyl- $\beta$-D-glucopyranose (5) was prepared by selective dibenzylation of 1,6-anhydro- $\beta$-D-glucopyranose using benzyl bromide and barium oxide in dimethylformamide according to the method of Iversen. ${ }^{16}$ 


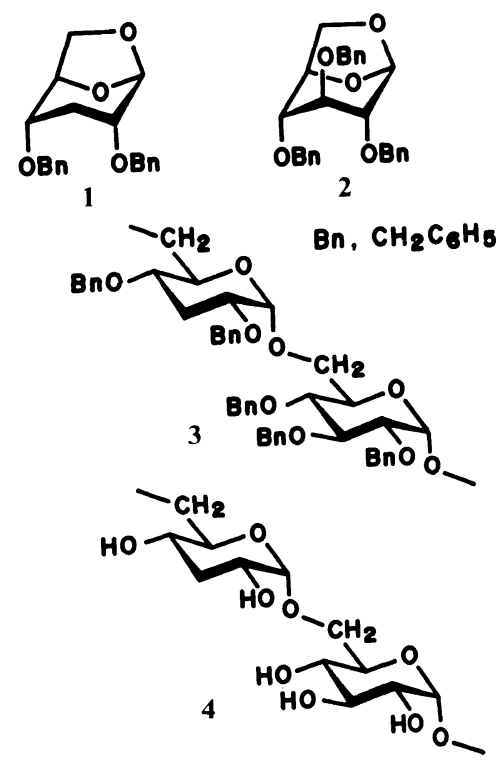

Scheme 1. Synthesis of deoxygenated $(1 \rightarrow 6)-\alpha-D-$ glucopyranans.

Yield, $92 \%$; mp, $104.5-105.5^{\circ} \mathrm{C} ;[\alpha]_{\mathrm{D}}^{25},-28.7$ (c 1.0, chloroform) (lit., ${ }^{16} \mathrm{mp}, 104.5-$ $\left.105.5^{\circ} \mathrm{C} ;[\alpha]_{\mathrm{D}}^{25},-28.8\right)$. The free hydroxyl group of $\mathbf{5}$ was thioacylated and the resulting imidazolyl or (methylthio)thiocarbonyl intermediates $\mathbf{6 a}$ and $\mathbf{6 b}$ were reduced with tributylstannane. $^{17}$

\section{1,6-Anhydro-2,4-di-O-benzyl-3-O-thiocar- bonylimidazolyl- $\beta$-D-glucopyranose (6a)}

A mixture of $5(4.28 \mathrm{~g}, 12.5 \mathrm{mmol})$ and $N, N^{\prime}$-thiocarbonyldiimidazole $(4.53 \mathrm{~g}, 25$ $\mathrm{mmol})$ in 1,2-dichloroethane $(63 \mathrm{ml})$ was refluxed gently for $3 \mathrm{hr}$. TLC (hexane-ethyl acetate, $1: 1, \mathrm{v} / \mathrm{v})$ showed almost complete conversion of $5(R f 0.6)$ to $\mathbf{6 a}(R f 0.4)$. The solution was washed with $1 \mathrm{~N} \mathrm{HCl}(63 \mathrm{ml}), 5 \%$ aqueous $\mathrm{NaHCO}_{3}$, and water $(63 \mathrm{ml})$. The organic solvent was removed in vacuo and the residue was chromatographed on silica gel. Elution with hexane-ethyl acetate $(3: 7, \mathrm{v} / \mathrm{v})$ followed by evaporation gave $\mathbf{6 a}$ as a syrup $\left(4.95 \mathrm{~g}, 88^{\circ} \%\right) \cdot[\alpha]_{\mathrm{D}}^{25},-60.5^{\circ}$ (c1 in chloroform). ${ }^{1} \mathrm{H} \mathrm{NMR}\left(\mathrm{CDCl}_{3}\right) 8.21,7.52$, and 6.98 (three s,
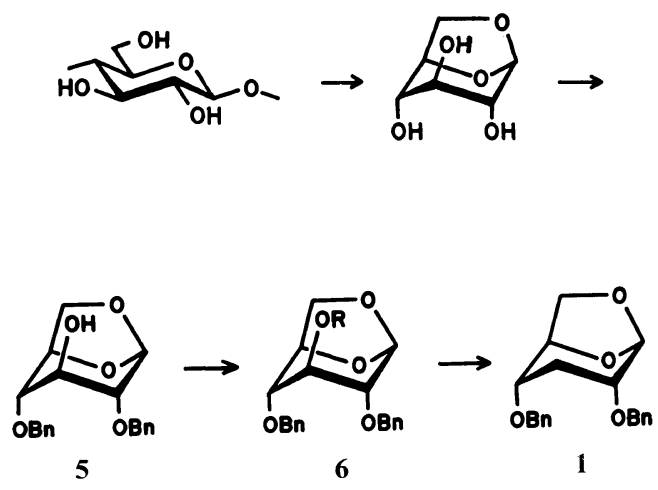

Bn, $\mathrm{CH}_{2} \mathrm{C}_{6} \mathrm{H}_{5}$

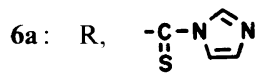

6b: $\mathrm{R}, \quad-\underset{\mathrm{s}}{\mathrm{C}}-\mathrm{SCH}_{3}$

Scheme II. Synthesis of 1,6-anhydro-2,4-di- $O$-benzyl3-deoxy- $\beta$-D-ribo-hexopyranose (1).

$3 \mathrm{H}$, imidazolyl), $\sim 7.29(10 \mathrm{H}$, phenyl), $5.76(\mathrm{~s}$, $1 \mathrm{H}, \mathrm{H}-3), 5.49$ (s, $1 \mathrm{H}, \beta-\mathrm{H}-1), 4.77$ and 4.71 (two s, $4 \mathrm{H}$, benzyl $\mathrm{CH}_{2}$ ), 4.57 (broad s, $1 \mathrm{H}, \mathrm{H}$ 5), $3.72\left(\mathrm{~s}, 2 \mathrm{H}, \mathrm{H}-6_{\text {exo }}\right.$ and $\left.\mathrm{H}-6_{\text {endo }}\right)$, and 3.39 ppm (s, 2H, H-2 and $\mathrm{H}-4) ;{ }^{13} \mathrm{C} \mathrm{NMR}\left(\mathrm{CH}_{2} \mathrm{Cl}_{2}\right.$, $\mathrm{Me}_{2} \mathrm{SO}-d_{6}$ external lock, $\left.25 \mathrm{MHz}\right) \quad 182.5$ $(\mathrm{C}=\mathrm{S}), 137.7,128.6,128.0$ (phenyl), 137.0, 131.2, and 118.2 (imidazolyl carbon), 100.2 (C1), 76.9, 74.6, and 74.3 (C-2, 3, 4, 5), 72.4 and 71.7 (benzyl $\mathrm{CH}_{2}$ ), and $65.4 \mathrm{ppm}$ (C-6). Anal. Calcd for $\mathrm{C}_{24} \mathrm{H}_{24} \mathrm{O}_{5} \mathrm{~N}_{2} \mathrm{~S}: \mathrm{C}, 63.70 \%$; $\mathrm{H}, 5.35 \%$; $\mathrm{N}, 6.19 \%$. Found: C, $63.42 \% ; \mathrm{H}, 5.42 \%, \mathrm{~N}$, $6.07 \%$.

\section{1,6-Anhydro-2,4-di-O-benzyl-3-O-(meth-} ylthio)thiocarbonyl- $\beta$-D-glucopyranose (6b)

Sodium hydride (oil dispersion, $50 \%, 4.0 \mathrm{~g}$ ) and imidazole $(40 \mathrm{mg})$ was added to $5(13.7 \mathrm{~g}$, $40 \mathrm{mmol}$ ) in dry tetrahydrofuran (THF, $120 \mathrm{ml}$ ) and the mixture was stirred under nitrogen for $2 \mathrm{~h}$. Carbon disulfide $(14.4 \mathrm{~g})$ was added and stirred for $2 \mathrm{~h}$; methyl iodide $(10 \mathrm{~g})$ was added and stirring was continued for $1 \mathrm{~h}$. Water $(40 \mathrm{ml})$ was added, the solution was 
concentrated in vacuo, and the residue was extracted with chloroform $(100 \mathrm{ml} \times 2)$. The chloroform solution was washed with $2 \%$ hydrochloric acid $(40 \mathrm{ml})$ and with saturated aqueous sodium bicarbonate $(40 \mathrm{ml})$, dried over magnesium sulfate and concentrated. The crude product was chromatographed on silica gel (hexane-ethyl acetate, $2: 1, \mathrm{v} / \mathrm{v}$ ) to give $\mathbf{6 b}$ as a yellow syrup. $18.1 \mathrm{~g}(\sim 100 \%)$. Anal. Calcd for $\mathrm{C}_{22} \mathrm{H}_{24} \mathrm{O}_{5} \mathrm{~S}_{2}: \mathrm{C}, 61.09 \%$; H, $5.59 \%$. Found: $61.08 \%$; H, $5.60 \%$.

\section{1,6-Anhydro-2,4-di-O-benzyl-3-deoxy- $\beta$-D- ribo-hexopyranose (1)}

A solution of $6 \mathrm{a}(2.7 \mathrm{~g}, 6.0 \mathrm{mmol})$ in dry toluene $(50 \mathrm{ml})$ was added dropwise over $30 \mathrm{~min}$ to tributylstannane $(2.7 \mathrm{~g}, 9.3 \mathrm{mmol})$ in toluene $(200 \mathrm{ml})$ with refluxing and stirring under nitrogen. After $2 \mathrm{~h}$, tributylstannane $(2.7 \mathrm{~g})$ was added again. Refluxing was continued for further $12 \mathrm{~h}$ until TLC analysis confirmed the disappearance of 6a. The solution was concentrated in vacuo, and the residue was dissolved in hexane $(50 \mathrm{ml})$ and extracted with acetonitrile $(30 \mathrm{ml} \times 4)$. The combined acetonitrile extracts were washed with hexane $(50 \mathrm{ml})$ and concentrated. Crystallization from ethanol and then purification by silica gel chromatography (hexaneethyl acetate, $2: 1, \mathrm{v} / \mathrm{v}$ ) yielded 1 as colorless crystal $(1.55 \mathrm{~g}, 79 \%)$.

$[\alpha]_{\mathrm{D}}^{25},-49.1^{\circ}(\mathrm{c} 1$ in chloroform $) ; \mathrm{mp} 60$ $60.5^{\circ} \mathrm{C} ;{ }^{1} \mathrm{H}-\mathrm{NMR}\left(\mathrm{CDCl}_{3}, 200 \mathrm{MHz}\right) 7.29$ $7.36(10 \mathrm{H}$, phenyl), 5.46 (s, $1 \mathrm{H}, \beta-\mathrm{H}-1), 4.61$ and 4.59 (two s, $5 \mathrm{H}$, benzyl $\mathrm{CH}_{2}$ and $\mathrm{H}-5$ ), $3.75\left(\mathrm{~d} \times \mathrm{d}, J=7\right.$ and $\left.5 \mathrm{~Hz}, 1 \mathrm{H}, \mathrm{H}-6_{\text {endo }}\right), 3.65$ $\left(\mathrm{d} \times \mathrm{d}, J=7\right.$ and $\left.1 \mathrm{~Hz}, 1 \mathrm{H}, \mathrm{H}-6_{\text {exo }}\right), 3.3(2 \mathrm{~d}$, $2 \mathrm{H}, \mathrm{H}-2$ and $\mathrm{H}-4), 2.04(\mathrm{~d}, J=15 \mathrm{~Hz}$ and $\mathrm{t}$, $\left.J=2,1 \mathrm{H}, \mathrm{H}-3_{\text {eq }}\right), 1.80 \mathrm{ppm}(\mathrm{d}, J=15 \mathrm{~Hz}$ and $\mathrm{t}$, $\left.J=6 \mathrm{~Hz}, 1 \mathrm{H}, \quad \mathrm{H}-3_{\mathrm{ax}}\right) ;{ }^{13} \mathrm{C} \mathrm{NMR}\left(\mathrm{CH}_{2} \mathrm{Cl}_{2}\right.$, $\mathrm{Me}_{2} \mathrm{SO}-d_{6}$ external lock) $138.8,128.5,127.8$, 127.6 (phenyl), 101.0 (C-1), 74.8 and 72.9 (C-2, 4, 5), 71.3 and 70.6 (benzyl $\mathrm{CH}_{2}$ ), 65.6 (C-6), and $24.8 \mathrm{ppm}$ (C-3). Anal. Calcd for $\mathrm{C}_{20} \mathrm{H}_{22} \mathrm{O}_{4}$ : $\mathrm{C}, 73.60 \%$;, $6.79 \%$. Found, C, $73.81 \%$; $6.84 \%$.
Compound $\mathbf{6 b}$ was treated in a similar way to give 1 in $91 \%$ yield.

\section{Polymerization}

1,6-Anhydro-2,3,4-tri- $O$-benzyl- $\beta$-D-glucopyranose was prepared by complete benzylation of 1,6 -anhydro- $\beta$-D-glucopyranose.

Polymerization was carried out in dichloromethane with high-vacuum techniques. ${ }^{4-7-9}$ Phosphorus pentafluoride was generated by heating $p$-chlorobenzenediazonium hexafluorophosphate. The polymerization was terminated by added cold methanol, and the precipitated polymer was purified by reprecipitation from chloroform into methanol four times and freezed-dried from benzene.

NMR and analytical data of the stereoregular homopolymer 2,4-di-O-benzyl-3-deoxy$(1 \rightarrow 6)-\alpha$-D-ribo-hexopyranan are as follows. ${ }^{1} \mathrm{H}$ NMR $\left(\mathrm{CDCl}_{3}, 9 \%, 60^{\circ} \mathrm{C}\right) 7.32$ and $7.27(2 \mathrm{~s}$, $10 \mathrm{H}$, phenyl), $4.96(\mathrm{~d}, J=3 \mathrm{~Hz}, 1 \mathrm{H}, \alpha-\mathrm{H}-1)$, 4.59 and $4.41(\mathrm{~d} \times \mathrm{d}, J=4 \mathrm{~Hz}, 4 \mathrm{H}$, benzyl $\left.\mathrm{CH}_{2}\right), 3.8-3.3\left(5 \mathrm{H}, \mathrm{H}-2,4,5,66_{\text {endo }}, 6_{\text {exo }}\right)$, $2.2-1.6 \mathrm{ppm}\left(2 \mathrm{H}, \quad \mathrm{H}-3_{\mathrm{eq}}\right.$ and $\left.\mathrm{H}-3_{\mathrm{ax}}\right) ;{ }^{13} \mathrm{C}$ NMR $\left(\mathrm{CH}_{2} \mathrm{Cl}_{2}, \quad 12 \%, \quad \mathrm{Me}_{2} \mathrm{SO}-d_{6}\right.$ external lock) 139.0, 128.5, and 127.7 (phenyl), $96.4(\alpha-$ C-1), 74.7 (C-2), 71.9 and 71.2 (C-4 and C-5), 70.7 (benzyl $\mathrm{CH}_{2}$ ), 65.4 (C-6), and $30.6 \mathrm{ppm}$ (C-3); Anal. Calcd for $\left(\mathrm{C}_{20} \mathrm{H}_{22} \mathrm{O}_{4}\right)_{\mathrm{n}}$ : C, $73.60 \%$; $\mathrm{H}, 6.79 \%$. Found: C, $73.84 \%$; H, $6.83 \%$.

\section{Determination of Equilibrium Monomer Con- centration}

Polymerization and depolymerization were carried out in a high vacuum reaction vessel equipped with a capillary tube to determine the reaction volume. A relatively low concentration of monomer and polymer solution in dichloromethane and a large amount of initiator $\left(\mathrm{PF}_{5}\right)$ were used. The reaction was terminated with methanol, the resulting solution was concentrated, and the conversion was determined from anomeric C-1 absorptions of the monomeric and polymeric components in ${ }^{13} \mathrm{C}$ NMR spectrum. 
Acid-Catalyzed Hydrolysis

1,6-Anhydro sugar compounds were dissolved in a mixture of trifluoroacetic acid and deuterium oxide $(6: 4, \mathrm{v} / \mathrm{v})$ in an NMR sample tube $(5 \mathrm{~mm} \phi)$ and the resulting solutions $\left(0.29 \mathrm{moll}^{-1}\right)$ were kept at $60^{\circ} \mathrm{C}$. The ${ }^{13} \mathrm{C}$ NMR peak intensity of the anomeric $\mathrm{C}-1$ signal were followed as a function of time and the hydrolysis rate was estimated from pseudo-firstorder plots.

\section{Debenzylation}

Debenzylation with sodium in liquid ammonia and work-up procedures were the same as those described previously. ${ }^{7-9}$

\section{Characterization}

${ }^{1} \mathrm{H}$ and ${ }^{13} \mathrm{C}$ NMR spectra were recorded on a Japan Electron Optics Laboratory JNMFX-200 Fourier transform NMR spectroscopy operated at 200 and $50 \mathrm{MHz}$, respectively. Optical rotations were determined with a JASCO DIP-181 digital polarimeter by using $1-\mathrm{dm}$ cell at $25^{\circ} \mathrm{C}$. Melting points (uncorrected) of 1,6-anhydrosugar derivatives were determined with a Yanagimoto melting point apparatus. Thermal analysis of polymers was made with a Perkin-Elmer DSC-2 differential scanning calorimeter. Gel-permeation chromatography was carried out by using a Shodex GPC-A $80 \mathrm{M}$ column $(8 \mathrm{~mm}$ i.d. $\times 1000 \mathrm{~mm}$ ) on a Hitachi 634A high-speed liquid chromatograph (solvent, chloroform). The calibration curve was made using standard samples of polystyrene. Solution viscosities were measured in Ubbelohde viscometers at $25^{\circ} \mathrm{C}$. TLC was carried out on Merck silica gel $60 \mathrm{~F}_{254}$ coated plates, and detection was made by charring with a $\mathrm{Ce}\left(\mathrm{SO}_{4}\right)_{2}$ solution in $3.6 \mathrm{~N}$ sulfuric acid.

\section{RESULTS AND DISCUSSION}

Homopolymerization of 1,6-Anhydro-2,4-di-Obenzyl-3-deoxy- $\beta$-D-ribo-hexopyranose (1)

Crystalline compound 1 was prepared as shown in Scheme II via thioacylation of the free hydroxyl group of 1,6-anhydro-2,4-di- $O$ benzyl- $\beta$-D-glucopyranose and subsequent reduction with tributylstannane. The overall yields through intermediates $\mathbf{6 a}$ and $\mathbf{6 b}$ were $70 \%$ and $82 \%$, respectively.

The polymerization of 1 was carried out under high vacuum with phosphorus pentafluoride as the initiator in dichloromethane. Table I summarizes the homopolymerization of 1 and characterization of the resulting polymers. The highest polymer yield was $95.6 \%$. The white powdery polymer obtained was soluble in solvents such as benzene, toluene, carbon tetrachloride, chloroform, dichloromethane, 1,2-dimethoxyethane, tetrahydrofuran, pyridine, dimethyl sulfoxide, dimethylformamide, and acetone.

Figure 1 shows the ${ }^{13} \mathrm{C}$ NMR spectra of polymers obtained by the polymerization below $-20^{\circ} \mathrm{C}$. In the $\mathrm{C}-1$ resonance regions, there appeared only one signal at $95.91 \mathrm{ppm}$ (peak c). The ${ }^{1} \mathrm{H}$ and ${ }^{13} \mathrm{C}$ NMR spectral data in the Experimental Section confirmed the formation of stereoregular 2,4-di-O-benzyl-3deoxy-( $1 \rightarrow 6)-\alpha$-D-ribo-hexopyranan. The high $\alpha$-anomeric stereoregularity was supported by positive and large optical rotation.

The polymer (exptl. no. S18 in Table I) obtained by 40 min's polymerization at $-60^{\circ} \mathrm{C}$ had the highest stereoregularity and highest molecular weight $\left(1.22 \times 10^{5}\right)$ among the homopolymers of 1 as judged by rotation, melting point, intrinsic viscosity, and GPC data. When polymerization was carried out at higher temperature and for a longer time, the intrinsic viscosity and estimated molecular weight of the polymer decreased. Optical rotation of the polymers, a sensitive measure of stereoregularity, was lowered with rise in polymerization temperature and prolonged time. In the ${ }^{13} \mathrm{C}$ NMR spectrum obtained by the polymerization at $0^{\circ} \mathrm{C}$, there appeared several small peaks assignable to the $\beta$-configurational unit, together with $\alpha$-configurational large peaks. The presence of about $6 \%$ of $\beta$-con- 
Polymerization of 1,6-Anhydrosugar Derivatives

Table I. Homopolymerization of 1,6-anhydro-2,4-di- $O$-benzyl-3-deoxy- $\beta$-D-ribo-hexopyranose (1) ${ }^{\mathrm{a}}$

\begin{tabular}{|c|c|c|c|c|c|c|c|c|}
\hline $\begin{array}{c}\text { Exptl. } \\
\text { No. }\end{array}$ & $\frac{\text { Temp }}{{ }^{\circ} \mathrm{C}}$ & $\frac{\text { Time }}{\mathrm{h}}$ & $\frac{\text { Yield }^{\mathrm{b}}}{\%}$ & $\frac{\alpha-\text { Form }^{c}}{\%}$ & $\frac{[\alpha]_{D}^{25 d}}{\operatorname{deg}}$ & $\frac{\mathrm{mp}^{\mathrm{e}}}{{ }^{\circ} \mathrm{C}}$ & $\frac{[\eta]^{\mathrm{f}}}{\mathrm{dl} \mathrm{g}^{-1}}$ & $\begin{array}{c}M_{n}{ }^{\mathrm{g}} \\
\times 10^{-4}\end{array}$ \\
\hline $\mathrm{S} 18$ & -60 & 0.67 & 58.1 & $\sim 100$ & +145.7 & $55-58$ & 0.99 & 12.2 \\
\hline S5 & -60 & 15 & 71.8 & $\sim 100$ & +143.4 & $40-45$ & 0.71 & 8.4 \\
\hline $\mathrm{S} 27^{\mathrm{h}}$ & -60 & 24 & 95.6 & $\sim 100$ & +138.9 & - & 0.22 & 2.9 \\
\hline S9 & -40 & 3 & 67.3 & $\sim 100$ & +141.9 & $54-57$ & 0.27 & 3.7 \\
\hline $\mathrm{S} 1$ & -20 & 0.67 & 79.6 & $\sim 100$ & +135.3 & $46-50$ & 0.18 & 2.0 \\
\hline S17 & 0 & 0.5 & 44.0 & 94 & +123.7 & $48-51$ & 0.08 & 1.4 \\
\hline S19 & 0 & 100 & 22.3 & 92 & +127.4 & $50-53$ & 0.08 & 1.4 \\
\hline
\end{tabular}

a Monomer, $3.0 \mathrm{mmol}$; initiator, $\mathrm{PF}_{5}, 3.3 \mathrm{~mol} \%$; solvent, dichloromethane, $2 \mathrm{ml}$.

b Methanol insoluble polymer.

c Determined by ${ }^{13} \mathrm{C}$ NMR spectra of both of benzylated and debenzylated polymers.

d $c, 1 \mathrm{~g} \mathrm{dl}^{-1}$ in chloroform.

e Determined by differential scanning calorimetry.

A At $25^{\circ} \mathrm{C}$ in chloroform.

$\mathrm{g}$ Determined by gel-permeation chromatography.

${ }^{\text {h }}$ Monomer, $10.1 \mathrm{mmol} ; \mathrm{PF}_{5}, 5.0 \mathrm{~mol} \%$; dichloromethane, $6 \mathrm{ml}$.

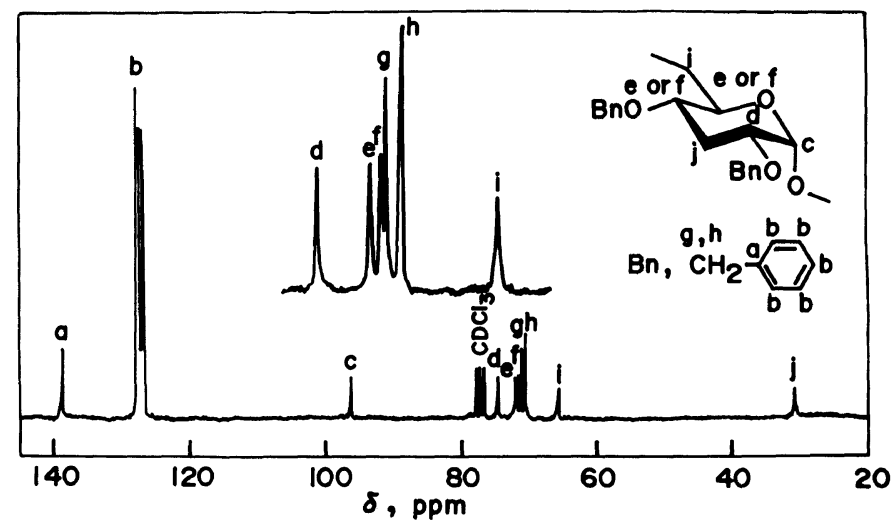

Figure 1. ${ }^{13} \mathrm{C}$ NMR spectrum of stereoregular 2,4-di- $O$-benzyl-3-deoxy-(1 $\left.\rightarrow 6\right)-\alpha$-D-ribo-hexopyranan. Concentration, $8 \%$ in $\mathrm{CDCl}_{3}$; room temp; TMS reference; $50 \mathrm{MHz}$.

figurational units and $94 \%$ of $\alpha$-configurational ones in the main chains was estimated from the area ratios of the $\beta-\mathrm{C}-1$ resonance at $105.8 \mathrm{ppm}$ and the $\alpha-\mathrm{C}-1$ resonance at $96.4 \mathrm{ppm}$.

Copolymerization between 1,6-Anhydro-2,4di-O-benzyl-3-deoxy- $\beta$-D-ribo-hexopyranose (1) and 1,6-Anhydro-2,3,4-tri-O-benzyl- $\beta$-Dglucopyranose (2)

The data on copolymerization between $\mathbf{1}$ and 2 at $-60^{\circ} \mathrm{C}$ are listed in Table II. The apparent copolymerization rate was high, and the termination in $10-20$ min resulted in $21-$ $46 \%$ conversion. The copolymer composition of 1 was higher than its feed composition as plotted in Figure 2. The solid curve illustrates the instantaneous copolymer composition calculated from the reactivity ratio of $r_{1}=1.60$ and $r_{2}=0.73$ as estimated by the Kelen-Tüdo's equation. ${ }^{18}$ The reactivity of monomer 1 toward the respective growing active centers was 
Table II. Copolymerization between 1,6-anhydro-2,4-di- $O$-benzyl-3-deoxy- $\beta$-D-ribo-hexopyranose (1) and 1,6-anhydro-2,3,4-tri- $O$-benzyl- $\beta$-D-glucopyranose $(2)^{\mathrm{a}}$

\begin{tabular}{|c|c|c|c|c|c|c|c|c|c|c|c|}
\hline \multirow{2}{*}{$\begin{array}{c}\text { Exptl. } \\
\text { No. }\end{array}$} & 1 & 2 & Mol. fr. & $\mathrm{CH}_{2} \mathrm{Cl}_{2}$ & Time & Yield & Mol. fr. & {$[\alpha]_{D}^{25 c}$} & $m p^{d}$ & {$[\eta]^{\mathrm{e}}$} & $M_{n}^{\mathrm{f}}$ \\
\hline & $\mathrm{mmol}$ & $\mathrm{mmol}$ & in feed & $\mathrm{ml}$ & $\min$ & $\%$ & copolymer $^{\mathbf{b}}$ & $\operatorname{deg}$ & ${ }^{\circ} \mathrm{C}$ & $\mathrm{dlg}^{-1}$ & \\
\hline S16 & 0 & 5.0 & 0 & 4 & 20 & 79.6 & 0 & +115.5 & $51-54$ & 0.67 & 2.6 \\
\hline $\mathrm{S} 11$ & 3.0 & 12.0 & 0.20 & 10 & 12 & 21.1 & 0.26 & +115.4 & $53-67$ & 0.72 & 1.8 \\
\hline S22 & 1.8 & 4.2 & 0.30 & 4 & 12 & 39.0 & 0.38 & +118.5 & $50-55$ & 0.49 & 1.8 \\
\hline$S 3^{g}$ & 2.0 & 3.5 & 0.36 & 4 & 10 & 33.1 & $0.49^{h}$ & +117.9 & $42-46$ & 0.73 & 1.3 \\
\hline $\mathrm{S} 24$ & 7.5 & 7.5 & 0.50 & 10 & 20 & 45.0 & 0.59 & +124.0 & $44-48$ & 0.79 & 1.4 \\
\hline $\mathrm{S} 23$ & 3.6 & 2.4 & 0.60 & 4 & 12 & 37.1 & 0.69 & +130.5 & $50-54$ & - & 1.9 \\
\hline $\mathrm{S} 10$ & 4.2 & 1.8 & 0.70 & 4 & 13 & 28.6 & 0.78 & +132.6 & $39-53$ & 0.65 & 1.4 \\
\hline $\mathrm{S} 25$ & 12.0 & 3.0 & 0.80 & 10 & 20 & 45.5 & 0.87 & +137.1 & $45-52$ & 0.86 & 1.2 \\
\hline S26 & 13.6 & 1.5 & 0.90 & 10 & 18 & 38.8 & 0.96 & +142.0 & $40-46$ & 1.07 & 1.8 \\
\hline $\mathrm{S} 18$ & 3.0 & 0 & 1.0 & 2 & 40 & 58.1 & 1.0 & +145.7 & $55-59$ & 0.99 & 1.2 \\
\hline
\end{tabular}

a Temp, $-60^{\circ} \mathrm{C}$; initiator, $\mathrm{PF}_{5}, 3.3 \mathrm{~mol} \%$.

b Determined from $50-\mathrm{MHz}{ }^{13} \mathrm{C}$ NMR spectra of debenzylated polymer.

c $c, 1 \mathrm{~g} \mathrm{dl}^{-1}$ in chloroform.

d Determined by differential scanning calorimetry.

e At $25^{\circ} \mathrm{C}$ in chloroform.

f Determined by gel-permeation chromatography.

g Initiator, $3.8 \mathrm{~mol}^{\%} \%$.

${ }^{\mathrm{h}}$ Determined from $25-\mathrm{MHz}^{13} \mathrm{C}$ NMR spectrum of benzylated copolymer.

higher than that of $\mathbf{2}$. Possibly, the replacement of electron-attractive benzyloxy substituent by hydrogen atom facilitates the approach of the monomer to growing ends owing to the enhanced nucleophilicity and reduced steric hindrance of the monomer.

The high $\alpha$-anomer stereoregularity of the copolymers was suggested by the high optical rotation and also ${ }^{13} \mathrm{C}$ NMR spectrum (Figure 3 ). Some of the resonances in the ${ }^{13} \mathrm{C} N M R$ spectrum were split into two peaks due to crossover diad sequences between $\mathbf{1}$ and $\mathbf{2}$ units. Figure 4 shows the splittings of $\alpha-\mathrm{C}-1$ anomeric resonances whose intensities varied with copolymer composition. The separation of the signals, however, was not enough to estimate each diad content.

\section{Etimation of Equilibrium Monomer Concentra- tion}

Equilibrium monomer concentration $\left([\mathrm{M}]_{\mathrm{e}}\right)$ was estimated from residual monomer concentrations $\left([\mathrm{M}]_{\mathrm{r}}\right)$ in polymerization and depolymerization as summarized in Table III.

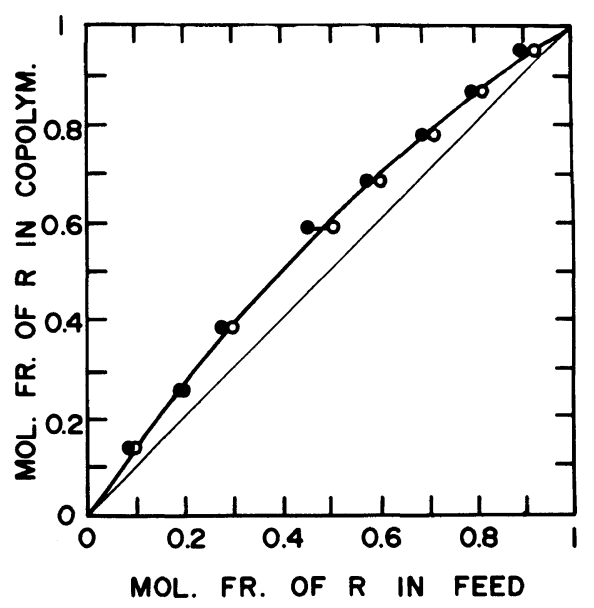

Figure 2. Composition curve for copolymerization between 1,6-anhydro-2,4-di- $O$-benzyl-3-deoxy- $\beta$-D-ribohexopyranose (1) and 1,6-anhydro-2,3,4-tri- $O$-benzyl- $\beta$ D-glucopyranose (2). The initial and final monomer compositions are shown as $\bigcirc$ and $\bigcirc$, respectively. $r_{1}=1.60$ and $r_{2}=0.73$.

Both reactions were carried out at $-60^{\circ} \mathrm{C}$ by applying low concentration of the starting compounds and a high concentration of the 


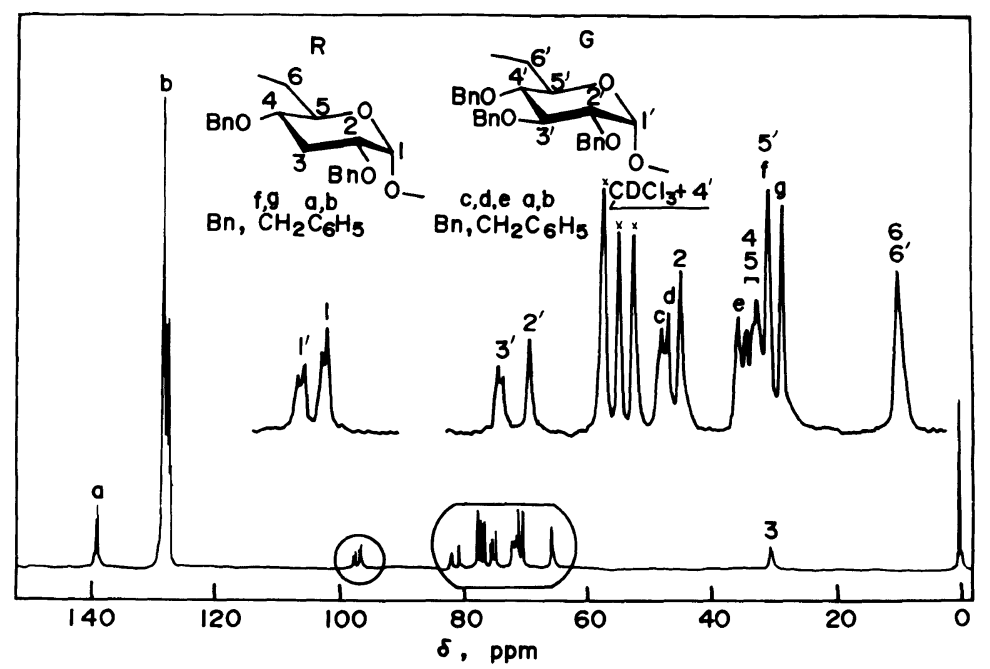

Figure 3. ${ }^{13} \mathrm{C}$ NMR spectrum of copolymer. Mole fraction of 1 in copolymer, 0.59 ; concentration; $9 \%$ in $\mathrm{CDCl}_{3} ; 43^{\circ} \mathrm{C}$; TMS reference; $50 \mathrm{MHz}$.

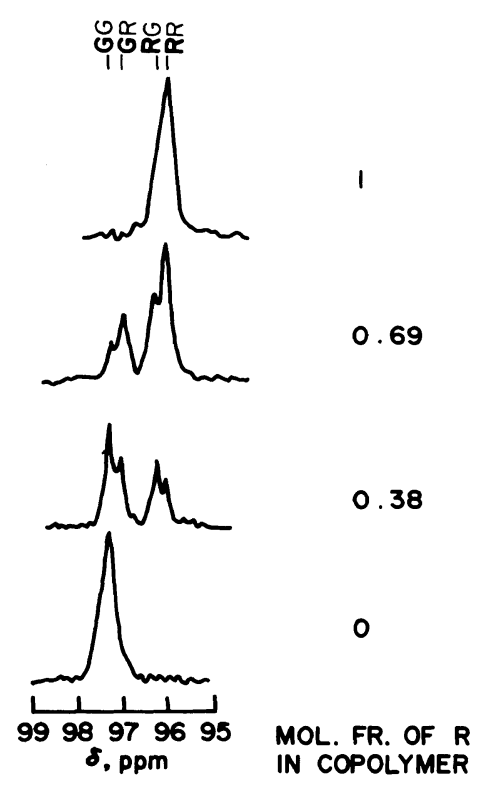

Figure 4. ${ }^{13} \mathrm{C}$ NMR spectra of anomeric carbon region of copolymers. In $\mathrm{CDCl}_{3}$; TMS reference; room temp; $50 \mathrm{MHz}$.

initiator. 1: $[\mathrm{M}]_{\mathrm{e}}=0.028-0.042 \mathrm{moll}^{-1} ; 2$ : $[\mathrm{M}]_{\mathrm{e}}=0.0064 \mathrm{~mol} \mathrm{1}^{-1}\left(\right.$ at $\left.-60^{\circ} \mathrm{C}\right)$. The free energy change in polymerization of 1 calculated from the $[\mathrm{M}]_{\mathrm{e}}$ value was less negative than that of $2\left(1,-5.9 \pm 0.4 \mathrm{~kJ} / \mathrm{mol} ; 2,-8.9 \mathrm{~kJ} \mathrm{~mol}^{-1}\right.$ at $\left.-60^{\circ} \mathrm{C}\right)$. We assumed that the absence of the benzyloxy substituent in position 3 released a large 1,3-diaxial interactions ${ }^{19}$ ) in the 1,6-anhydro form, resulting in a less favorable thermodynamic reactivity of $\mathbf{1}$.

\section{Acid-Catalyzed Hydrolysis}

Hydrolysis rates of several bicyclic acetal using dichloroacetic acid as catalyst were compared in the literature, ${ }^{5,20}$ but this catalytic system was not strong enough to hydrolyze 1 and 2 at measurable rates because both compounds are stabilized by an electron attractive benzyloxy group at position 2. A mixture of trifluoroacetic acid and deuterium oxide (vol ume ratio of $6: 4$ ) has been found to cause the acid-catalyzed solvolysis of 1 and 2 at $60^{\circ} \mathrm{C}$. The rates were followed by the disappearance of the $\beta-C-1$ carbon signals. The compound 1 was hydrolyzed at a rate of $2.4 \times 10^{-5} \mathrm{~s}^{-1}$, and 2 of $7.3 \times 10^{-6} \mathrm{~s}^{-1}$. The ring-opening reactivity of 1 was 3.2-fold over that of 2 .

\section{3-Deoxygenated $(1 \rightarrow 6)-\alpha-D-G l u c o p y r a n a n$}

Debenzylation of the homopolymers (3) using sodium in liquid ammonia is shown in Table IV. In the ${ }^{13} \mathrm{C}-\mathrm{NMR}$ spectra of the 
Table III. Determination of equilibrium monomer concentration through polymerization of $\mathbf{1}$ and $\mathbf{2}$ and depolymerization of each homopolymer ${ }^{\mathrm{a}}$

\begin{tabular}{|c|c|c|c|c|c|}
\hline Starting compound & & $\mathrm{PF}_{5}$ & Time & Convn. ${ }^{b}$ & {$[\mathrm{M}]_{\mathrm{r}}^{\mathrm{c}}$} \\
\hline & $\mathrm{moll}^{-1}$ & $\mathrm{~mol}^{\circ} \%$ & Day & $\%$ & $\mathrm{moll}^{-1}$ \\
\hline 1 & 0.28 & 13 & 1 & 85.0 & 0.042 \\
\hline Homopolymer of 1 & 0.076 & 14 & 6 & 37.7 & 0.029 \\
\hline 2 & 0.28 & 13 & 2 & 97.7 & 0.0064 \\
\hline Homopolymer of 2 & 0.097 & 20 & 5 & 6.5 & 0.0063 \\
\hline
\end{tabular}

a At $-60^{\circ} \mathrm{C}$ in dichloromethane.

b Determined by ${ }^{13} \mathrm{C}$ NMR spectroscopy.

c Residual monomer concentration.

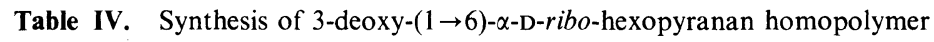

\begin{tabular}{|c|c|c|c|c|c|c|c|c|c|c|}
\hline \multirow{2}{*}{$\begin{array}{c}\text { Exptl. } \\
\text { No. }\end{array}$} & \multirow{2}{*}{$\frac{\text { Weight }}{\mathrm{g}}$} & \multirow{2}{*}{$\frac{\mathrm{Na}}{\mathrm{g}}$} & \multirow{2}{*}{$\frac{\mathrm{NH}_{3}}{\mathrm{ml}}$} & \multirow{2}{*}{$\frac{\text { Toluene }}{\mathrm{ml}}$} & \multirow{2}{*}{$\frac{\mathrm{DME}^{\mathrm{a}}}{\mathrm{ml}}$} & \multirow{2}{*}{$\frac{\text { Time }}{\mathrm{h}}$} & \multirow{2}{*}{$\frac{\text { Yield }}{\%}$} & \multirow{2}{*}{$\frac{[\alpha]_{\mathrm{D}}^{25 b}}{\operatorname{deg}}$} & \multirow{2}{*}{$\frac{[\eta]^{\mathrm{c}}}{\mathrm{dlg}^{-1}}$} & \multirow{2}{*}{$\begin{array}{c}M_{n}{ }^{d} \\
\times 10^{-4}\end{array}$} \\
\hline & & & & & & & & & & \\
\hline DS18 & 0.47 & 0.12 & 50 & 15 & 5 & 2 & $\sim 100$ & +125 & 0.59 & - \\
\hline DS27 & 2.94 & 0.88 & 250 & 90 & 30 & 2 & $\sim 100$ & +154 & 0.31 & 1.0 \\
\hline DS1 & 0.43 & 0.80 & 50 & 15 & 5 & 1.5 & $\sim 100$ & +128 & 0.13 & 0.67 \\
\hline DS 17 & 0.28 & 0.15 & 30 & 7.5 & 2.5 & 1.5 & 88 & - & 0.05 & - \\
\hline
\end{tabular}

a 1,2-Dimethoxyethane.

b $c, 1.0$ in water.

c At $25^{\circ} \mathrm{C}$ in $\mathrm{Me}_{2} \mathrm{SO}$.

d Estimated by GPC (pullulan standard in water).

products of the exptl. nos. DS18 and DS27, there appeared only six resonances whose chemical shifts are listed in Table V (the spectrum was presented in the preliminary communication $^{7)}$. Table $\mathrm{V}$ also shows that each ${ }^{1} J\left({ }^{13} \mathrm{C}-{ }^{1} \mathrm{H}\right)$ coupling constant was similar to the corresponding one of $(1 \rightarrow 6)-\alpha-D-g l u-$ copyranan except for that of the C-3 carbon. The stereoregular polysaccharide 3deoxy-( $1 \rightarrow 6)-\alpha$-D-ribo-hexopyranan was soluble in water and dimethyl sulfoxide. Anal. Calcd for $\left(\mathrm{C}_{6} \mathrm{H}_{10} \mathrm{O}_{4}\right)_{n}: \mathrm{C}, 49.31 \%, \mathrm{H}, 7.09 \%$. Found: $\mathrm{C}, 49.31 \%, \mathrm{H}, 6.90 \%$.

The polysaccharide containing $6 \%$ of the $\beta$ configurational unit in the main chain was also obtained by debenzylation of polymer S17. The NMR data (in $\mathrm{D}_{2} \mathrm{O}, 70^{\circ} \mathrm{C}$ ) of the $\alpha$ - and $\beta$ anomer carbons and protons are as follows: ${ }^{13} \mathrm{C}$ NMR: $\alpha-\mathrm{C}-1,97.80 ; \beta-\mathrm{C}-1,105.5 .{ }^{1} \mathrm{H}$ NMR: $\alpha-\mathrm{H}-1,4.83, J_{1,2}=3.2 \mathrm{~Hz} ; \beta-\mathrm{H}-1,4.44$,
Table V. Chemical shifts and ${ }^{1} J\left({ }^{13} \mathrm{C}-{ }^{1} \mathrm{H}\right)$ coupling constants of 3-deoxy-( $1 \rightarrow 6)-\alpha$-D-ribo-hexopyranan and $(1 \rightarrow)-\alpha$-D-glucopyranan ${ }^{\mathrm{a}}$

\begin{tabular}{|c|c|c|c|c|}
\hline & \multicolumn{2}{|c|}{$\begin{array}{l}\text { 3-Deoxy- }(1 \rightarrow 6)-\alpha-\mathrm{D}- \\
\text { ribo-hexopyranan }\end{array}$} & \multicolumn{2}{|c|}{$\begin{array}{c}(1 \rightarrow 6)-\alpha-D-G l u c o- \\
\text { pyranan }\end{array}$} \\
\hline & \multirow{2}{*}{ ppm } & ${ }^{1} J\left({ }^{13} \mathrm{C}-{ }^{1} \mathrm{H}\right)$ & \multirow{2}{*}{ ppm } & ${ }^{1} J\left({ }^{13} \mathrm{C}-{ }^{1} \mathrm{H}\right)$ \\
\hline & & $\mathrm{Hz}$ & & $\mathrm{Hz}$ \\
\hline C-1 & 97.80 & 169.0 & 98.83 & 170.9 \\
\hline C-2 & 67.74 & 144.5 & 72.55 & 144.7 \\
\hline C-3 & 36.11 & 129.9 & 74.53 & 146.7 \\
\hline C-4 & 65.25 & 145.5 & 70.92 & 142.8 \\
\hline C-5 & 72.22 & 144.5 & 71.36 & 142.8 \\
\hline C-6 & 66.52 & 144.0 & 67.06 & 144.7 \\
\hline
\end{tabular}

a Concentration, $10 \%$ in $\mathrm{D}_{2} \mathrm{O}$; temp, $70^{\circ} \mathrm{C}$; TMS external reference; $50 \mathrm{MHz}$.

$J_{1,2}=7.3 \mathrm{~Hz}$.

Debenzylation of copolymers between 1 and 2 gave high $\alpha$-stereoregular copolysaccharides 
Polymerization of 1,6-Anhydrosugar Derivatives

Table VI. Synthesis of copolysaccharide 4

\begin{tabular}{|c|c|c|c|c|c|c|c|c|c|c|}
\hline \multirow{2}{*}{$\begin{array}{c}\text { Exptl. } \\
\text { No. }\end{array}$} & \multirow{2}{*}{$\frac{\text { Weight }}{\mathrm{g}}$} & \multirow{2}{*}{$\frac{\mathrm{Na}}{\mathrm{g}}$} & \multirow{2}{*}{$\frac{\mathrm{NH}_{3}}{\mathrm{ml}}$} & \multirow{2}{*}{$\frac{\text { Toluene }}{\mathrm{ml}}$} & \multirow{2}{*}{$\frac{\mathrm{DME}^{\mathrm{a}}}{\mathrm{ml}}$} & \multirow{2}{*}{$\frac{\text { Time }}{\mathrm{h}}$} & \multirow{2}{*}{$\frac{\text { Yield }}{\%}$} & \multirow{2}{*}{$\frac{[\alpha]_{\mathrm{D}}^{25 \mathrm{~b}}}{\operatorname{deg}}$} & \multirow{2}{*}{$\frac{[\eta]^{\mathrm{c}}}{\mathrm{dl} \mathrm{g}^{-1}}$} & \multirow{2}{*}{$\begin{array}{l}M_{n}{ }^{\mathrm{d}} \\
\times 10^{-4}\end{array}$} \\
\hline & & & & & & & & & & \\
\hline DS16 & 1.25 & 0.54 & 125 & 50 & 13 & 1.5 & $\sim 100$ & +162 & 0.23 & - \\
\hline DS11 & 1.00 & 1.06 & 100 & 30 & 10 & 2.0 & $\sim 100$ & +165 & 0.21 & 1.4 \\
\hline DS22 & 0.76 & 1.31 & 100 & 30 & 10 & 1.5 & 73 & +155 & 0.34 & 2.6 \\
\hline DS24 & 2.20 & 0.73 & 200 & 60 & 20 & 1.7 & 73 & +170 & 0.69 & 4.5 \\
\hline $\mathrm{DS} 23$ & 0.73 & 1.00 & 100 & 30 & 10 & 1.5 & 98 & +161 & 0.35 & 2.2 \\
\hline DS10 & 0.41 & 0.49 & 50 & 15 & 5 & 1.0 & 96 & +151 & 0.21 & 1.3 \\
\hline DS25 & 2.03 & 0.67 & 200 & 60 & 20 & 2.5 & 97 & +147 & 0.56 & 3.4 \\
\hline DS26 & 1.65 & 0.47 & 200 & 60 & 20 & 1.5 & 85 & +168 & 0.71 & 5.2 \\
\hline DS18 & 0.47 & 0.12 & 50 & 15 & 5 & 1.0 & $\sim 100$ & +154 & 0.59 & - \\
\hline
\end{tabular}

a 1,2-Dimethoxyethane.

${ }^{b} c, 1.0$ in water.

c At $25^{\circ} \mathrm{C}$ in $\mathrm{Me}_{2} \mathrm{SO}$.

d Estimated by GPC (pullulan standard in water).

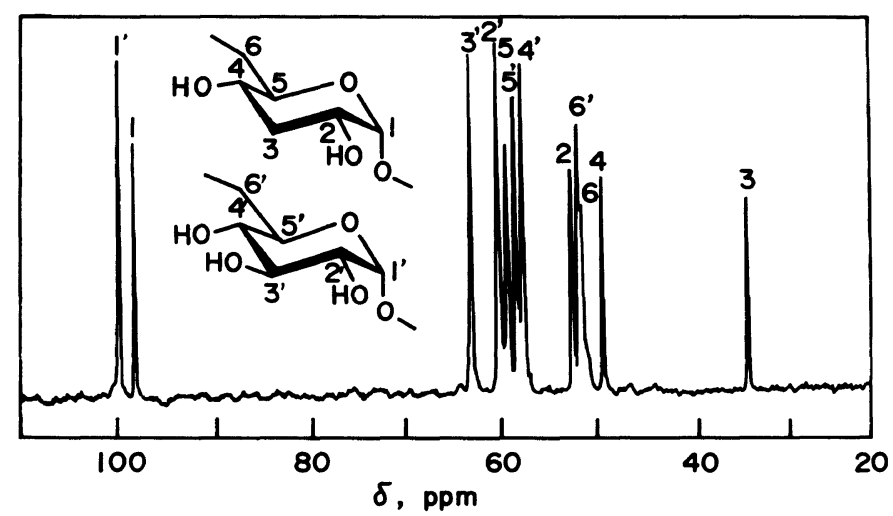

Figure 5. ${ }^{13} \mathrm{C}$ NMR spectrum of a debenzylated copolysaccharide. Mole fraction of deoxygenated unit, 0.36 ; concentration, $10 \%$ in $\mathrm{D}_{2} \mathrm{O}$; external reference, TMS; $50 \mathrm{MHz}$.

consisting of 3-deoxygenated and nondeoxygenated $(1 \rightarrow 6)-\alpha$-D-glucopyranan units (Table VI). Figure 5 represents one of their ${ }^{13} \mathrm{C}$ NMR spectra. No signal splitting due to crossover diad sequences was observed, in contrast to the splitting of benzylated copolymers (Figures 3 and 4). The $\alpha-\mathrm{C}-1$ resonance of each structural unit was completely separated from the others, and the copolymer compositions given in Table II are those estimated from their area ratios.

Thus, well-defined $(1 \rightarrow 6)-\alpha$-D-glucopyranans with different degrees of deoxygena- tion have been prepared. Enzymatic hydrolysis using an endo-acting dextranase suggests that the deoxygenated sequences are bound to the enzyme but not hydrolyzed. ${ }^{21}$ The data will be given elsewhere.

\section{REFERENCES}

1. N. R. Williams and J. D. Wander, "The Carbohydrates: Chemistry and Biochemistry," Vol. IB, W. Pigman and D. Horton, Ed., Academic Press, New York, N. Y., 1980, p 761.

2. U. Spohr, O. Hindsgaul, and R. U. Lemieux, Can. J. Chem., 63, 2644 (1985). 
3. R. U. Lemieux, A. P. Venot, U. Spohr, P. Bird, G. Mandal, N. Morishima, O. Hindsgaul, and D. R. Bundle, Can. J. Chem., 63, 2661 (1985).

4. C. Schuerch, Adv. Carbohydr. Chem. Biochem., 39, 157 (1981).

5. H. Sumitomo and M. Okada, "Current Topics in Polymer Science," Vol. 1, R. M. Ottenbrite, L. A. Utracki, and S. Inoue, Ed., Hanser, Munich, 1987, p 15.

6. N. K. Kochetkov, Tetrahedron, 43, 2389 (1987).

7. K. Kobayashi and H. Sumitomo, Macromolecules, 16, 710 (1983).

8. K. Kobayashi and H. Sumitomo, Carbohydr. Res., 115, 243 (1983).

9. K. Kobayashi, H. Sumitomo, H. Ichikawa, and H. Sugiura, Polym. J., 18, 927 (1986).

10. K. Hatanaka, S. Kanazawa, and T. Uryu, J. Polym. Sci., Polym. Chem. Ed., 22, 1987 (1984).

11. M. Okada, H. Sumitomo, and Y. Hishida, Makromol. Chem., 184, 1823 (1983).
12. M. Okada, H. Sumitomo, A. Sumi, and T. Sugimoto, Macromolecules, 17, 2451 (1984).

13. T. Uryu, Y. Sakamoto, K. Hatanaka, and K. Matsuzaki, Macromolecules, 17, 1307 (1984).

14. T. Uryu, H. Tachikawa, K. Ohaku, K. Terui, and K. Matsuzaki, Makromol. Chem., 178, 1929 (1977).

15. K. Kobayashi and C. Schuerch, J. Polym. Sci., Polym. Chem. Ed., 15, 913 (1977).

16. T. Iversen and D. R. Bundle, Can. J. Chem., 60, 299 (1982).

17. D. H. R. Barton and S. W. McCombie, J. Chem. Soc., Perkin Trans. I, 1574 (1975).

18. T. Kelen and F. Tüdós, J. Macromol. Sci., Polym. Chem. Ed., 15, 913 (1977).

19. S. J. Angyal, Aust. J. Chem., 21, 2737 (1968).

20. H. K. Hall, Jr., L. J. Carr, R. Kellman, and F. DeBlauwe, J. Am. Chem. Soc., 96, 7265 (1974).

21. K. Kobayashi, H. Sumitomo, and H. Shiozawa, Abstracts of Papers, Japan-U.S. Polymer Symposium, Kyoto, Oct. 29-Nov. 1, 1985, p 151. 